\title{
Vertical migration, nutrition and toxicity in the dinoflagellate Alexandrium tamarense
}

\author{
J. Geoff MacIntyre ${ }^{1, *}$, John J. Cullen ${ }^{1}$, Allan D. Cembella ${ }^{2}$ \\ ${ }^{1}$ Center for Environmental Observation Technology and Research, Department of Oceanography, Dalhousie University, \\ Halifax, Nova Scotia, Canada B3H $4 \mathrm{~J} 1$ \\ ${ }^{2}$ Institute For Marine Biosciences, National Research Council, Halifax, Nova Scotia, Canada B3H $3 Z 1$
}

\begin{abstract}
The effect of nitrate-N availability on paralytic shellfish toxin production by the dinoflagellate Alexandrium tamarense was studied in a vertically stratified laboratory water column (tank) where swimming behavior could influence photosynthesis and nutrition. Results were compared with those from batch and semi-continuous cultures in which migratory behavior was not a factor. The batch and semi-continuous cultures demonstrated a direct positive relationshup between $\mathrm{N}$ availability and toxin content. Steady-state cultures, maintained at 2 contrasting rates of semi-continuous $\mathrm{N}$ supply, also demonstrated significantly different cellular toxin profiles (relative proportion of toxins). The tank experiment was carried out in a $2.1 \mathrm{~m}$ PVC cylinder $(0.29 \mathrm{~m}$ internal dameter) and lasted for $24 \mathrm{~d}$. Initially, nitrate was replete throughout the water column $(50 \mu \mathrm{M})$ and the highly toxic cells formed a thin surface layer which persisted throughout the $14 \mathrm{~h}$ light: $10 \mathrm{~h}$ dark cycle. When nitrate was depleted in the surface layer as a result of uptake by the phytoplankton, the cells began a nocturnal migration to the nitracline. During this phase the toxin content of the cells decreased gradually as the C:N of the cells increased. In the third phase, the deep nitrate pool was exhausted and the cells penetrated deeper during the dark period. The toxin content of the cells reached the lowest level during this phase. When nitrate was added to the deep layer, a fourth phase began, during which nocturnal descent of the migrating cells was again restricted to the nitracline; toxicity of the cells increased and $\mathrm{C}: \mathrm{N}$ declined. Finally, $\mathrm{N}$ was added to the surface layer. During this fifth and final phase, cellular toxicity continued to rise, $C: N$ declined further, and the cells continued to migrate to the thermocline during the dark period. The toxicity of the cells during the $\mathrm{N}$-stratified phases of the water column experiment was intermediate between the $\mathrm{N}$-replete and $\mathrm{N}$-depleted phases, indicating that $\mathrm{A}$. tamarense is capable of producing PSP toxins from $N$ acquired during a nocturnal descent. It is concluded that toxic dinoflagellates inhabiting $\mathrm{N}$-depleted coastal waters are likely capable of sustaining growth and a moderate level of toxicity through nocturnal migrations to deep $N$ pools.
\end{abstract}

KEY WORDS: Alexandrium tamarense PSP Vertical migration - Nitrogen - Dinoflagellate - Toxin profile $\cdot \mathrm{N}$-stratified $\cdot$ Red-tide

\section{INTRODUCTION}

Paralytic Shellfish Poisoning (PSP) is a severe affliction of the vertebrate nervous system caused by the ingestion of shellfish or finfish which have consumed dinoflagellates that produce PSP toxins. A single incidence of PSP can cause closure of shellfish harvesting over widespread areas, eliminating both an important source of income and a valuable source of protein

-E-mail: geoff@predator.ocean.dal.ca
(White et al. 1992, Busto et al. 1993). A better understanding of the ecophysiology of toxin producers, as well as the factors and relationships involved in the production of PSP toxins, is required to more effectively manage coastal waters where PSP is a factor

Dinoflagellates of the genus Alexandrium have been implicated as causative organisms in PSP around the world and they pose a widespread threat to shellfish and finfish resources. The toxin content of such PSP producing phytoplankton is known to vary with environmental conditions such as salinity (White 1978), 
temperature (Anderson et al. 1990b), photon flux density (Ogata et al. 1987) and nutrient levels (Boyer et al. 1987. Anderson et al. 1990b, Flynn et al. 1994) and also with growth stage (Boczar et al. 1988), growth rate (Ogata et al. 1987) and cell cycle (Anderson 1990). Although studies have shown a strong relationship between phosphorus limitation and toxicity (Boyer et al. 1987, Anderson et al. 1990b), we focus here on the positive relationship between inorganic $N$ availability and PSP toxin content in toxic dinoflagellates of the genus Alexandrium (Boyer et al. 1987. Anderson et al. 1990b. Flynn et al. 1994). Because toxic dinoflagellates typically inhabit coastal nearshore areas (Cembella \& Therriault 1989, Iwasaki 1989) which are frequently limited by nitrogen (Ryther \& Dunstan 1971, Boekel et al. 1992; but see Sakshaug \& Jensen 1971 concerning phosphorus-limited fjords), and periodically $N$ stratified, the relationship between toxin content and $N$ limitation is relevant in nature and needs to be further understood.

Several species of dinoflagellates are known to perform diel vertical migrations (DVM) through gradients of nutrients and temperature in both natural (Eppley \& Harrison 1975, Kiefer \& Lasker 1975, Blasco 1978) and laboratory conditions (Eppley et al. 1968, Cullen \& Horrigan 1981, Heaney \& Eppley 1981, Kamykowski 1981, Cullen et al. 1985, Rasmussen \& Richardson 1989, Santos \& Carretto 1992j. Migrational behavior consequently enables dinoflagellates to utilize deep $\mathrm{N}$ pools (Fraga et al. 1992) and confers some competitive advantage for phytoplankton in $\mathrm{N}$-depleted surface waters (Holmes et al. 1967). Thus, N-stratified coastal waters with a steep thermocline provide an environment which is suitable for bloom formation by vertically migrating dinoflagellates. Although the toxic dinoflagellate Alexandrium tamarense does not reach high standing stocks generally, it is known to form dense near-surface populations in coastal waters (Sakshaug \& Jensen 1971, Anderson \& Stolzenbach 1985 Iwasaki 1989, Carretto et al. 1990, Esteves et al. 1992, Rensel 1993) and has demonstrated directed swimming ability in laboratory conditions (Rasmussen \& Richardson 1989, Santos \& Carreto 1992); consequently, we hypothesize that this species has the ability to migrate vertically to deep pools of nitrogen. Given the effects of nutrition on the toxicity of $A$. tamarense, a diel migration between high and low levels of $\mathrm{N}$ availability by this toxic dinoflagellate might influence cellular toxicity in a manner that could not be simulated in conventional lab experiments.

Although behavior seems likely to have a large influence on the ecophysiology of dinoflagellate populations in nature, such effects on the toxicity of dinoflagellates have yet to be addressed. While conventional laboratory experiments have proved extremely useful in working out relationships between nutrition and toxicity (Boyer et al. 1987. Anderson et al. 1990b), cultures in small containers clearly cannot be used to study the consequences of vertical migration through gradients of light, temperature and nutrients. Here, we describe an experiment in a laboratory water column that was designed to elucidate both the pattern of DVM as influenced by the distribution of nitrate and its effects on toxicity in Alexandrium tamarense. In addition to presenting such results for the first time, the effects of $\mathrm{N}$ starvation in batch cultures and $\mathrm{N}$ limitation in semi-continuous cultures are re-examined with a new focus.

\section{MATERIALS AND METHODS}

Nitrate-stratified laboratory water column. To examine the relationships between behavior, nutrition and toxicity, a thermally stratified water column (Fig. 1) was established in a single opaque polyvinyl chloride (PVC) cylinder $2.10 \mathrm{~m}$ in height with an internal diameter of $0.29 \mathrm{~m}$ (Heaney \& Eppley 1981). The tank was in an environmentally controlled room at a temperature of $\sim 17^{\circ} \mathrm{C}$. A thermocline was established and maintained using a temperature-controlled, circulating water bath $\left(5^{\circ} \mathrm{C}\right)$ to cool the bottom $100 \mathrm{~cm}$ of the tank. Temperature ranged from approximately $17.0^{\circ} \mathrm{C}$ at the surface to $7.4^{\circ} \mathrm{C}$ at the bottom with the major thermocline occurring between 100 and $140 \mathrm{~cm}$ depth with a 6 to $7^{\circ} \mathrm{C}$ decrease in temperature. Irradiance was provided by a $250 \mathrm{~W}$ metal halide lamp on a $14 \mathrm{~h}$

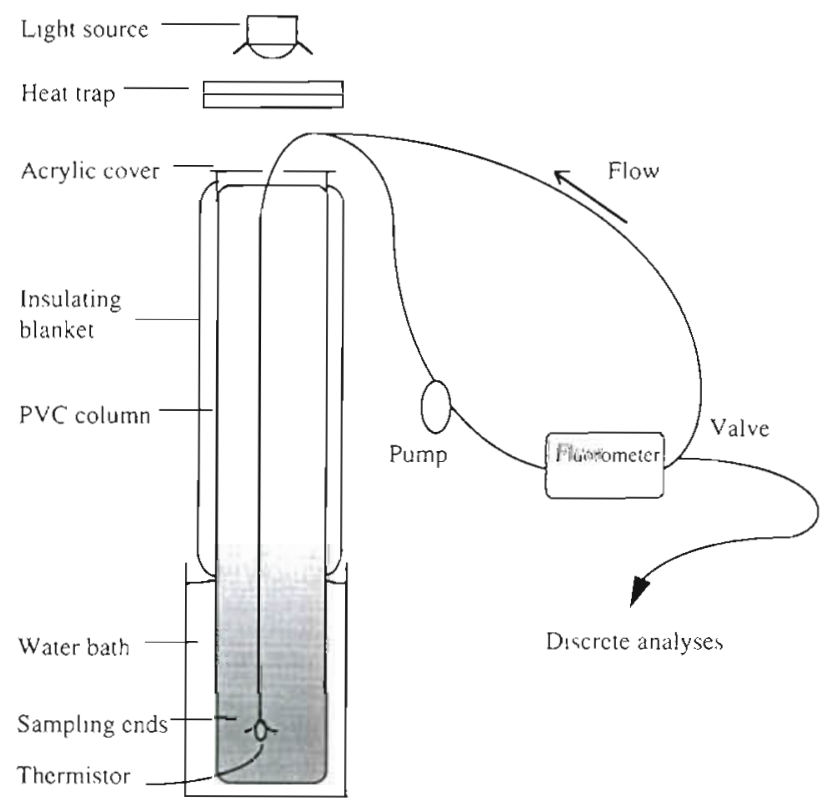

Fig. 1. Laboratory water column used for tank experiment 
light: 10 h dark cycle with the light period from 08:00 to $22: 00 \mathrm{~h}$. Irradiance, measured in situ (prior to inoculation) with a $\mathrm{Li}$-Cor ( $\mathrm{Li}$ 185B) $4 \pi$ PAR photometer, ranged from $390 \mu \mathrm{mol}$ quanta $\mathrm{m}^{-2} \mathrm{~s}^{-1}$ at the surface to $17.5 \mu \mathrm{mol}$ quanta $\mathrm{m}^{-2} \mathrm{~s}^{-1}$ at the bottom. Enriched seawater ( $\mathrm{K}$ medium; Keller et al. 1987), with $\mathrm{NO}_{3}{ }^{-}$and $\mathrm{PO}_{4}{ }^{3-}$ concentrations modified to $50 \mu \mathrm{M}$ and $20 \mu \mathrm{M}$ respectively, was sterile-filtered $(0.2 \mu \mathrm{m}$ Gelman Culture Capsule filter) directly into the tank. An inoculum consisting of seven $1 \mathrm{l}$ cultures of exponentially growing Alexandrium tamarense (Pr18b), a highly toxic strain isolated from the lower St. Lawrence estuary in eastern Canada, was grown at $140 \mu \mathrm{mol}$ quanta $\mathrm{m}^{-2} \mathrm{~s}^{-1}$ on a $14 \mathrm{~h}$ light: $10 \mathrm{~h}$ dark cycle in $\mathrm{K}$ medium. The inoculum was added gently to the top layer of the tank. The final volume of the medium was approximately $120 \mathrm{l}$ with an initial cell density of approximately $4.0 \times 10^{2}$ cells $\mathrm{ml}^{-1}$. The water column was then mixed thoroughly through gentle aeration from the bottom for $10 \mathrm{~min}$.

The tank was sampled using a single length of silicone tubing (1.6 mm internal diameter) run through a Turner Designs fluorometer and looped back along itself to make a doubled sampling line (inflow and outflow) which was lowered through a small opening in the center of the acrylic cover and into the center of the water column. A thermistor cable was run along the sampling line to the sampling end which was weighted with a Teflon covered stir bar where the thermistor was exposed. Samples were obtained by pumping tank

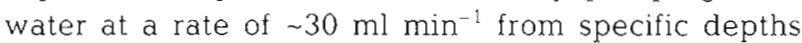
(every $20 \mathrm{~cm}$ from the surface to the bottom) using a Masterflex peristaltic pump (Cullen \& Horrigan 1981). A valve in the sampling line allowed the collection of discrete samples $(\sim 300$ to $400 \mathrm{ml})$ for cell counts, chlorophyll a (chl a) concentration, fluorescence before and after the addition of the photosynthetic inhibitor DCMU [3-(3,4-dichlorophenyl)-1,1-dimethylurea], particulate $\mathrm{C}$ and $\mathrm{N}$, inorganic macronutrient concentrations $\left(\mathrm{NO}_{3}{ }^{-}, \mathrm{NO}_{2}{ }^{-}, \mathrm{PO}_{4}{ }^{3-}, \mathrm{NH}_{4}{ }^{+}\right)$and PSP toxin analysis. Samples were taken at 4 depths representing strata or features in the fluorescence profile (e.g. 0, 60, 120, $200 \mathrm{~cm}$ ). Physiological parameters (cellular fluorescence capacity; Vincent 1980, described below) of samples passed through the pump were similar to those sampled directly, indicating that pumping did not adversely affect the cells. To maintain the volume of medium in the tank (sampling removed $-1.51 \mathrm{~d}^{-1}$ ), cooled $\left(7^{\circ} \mathrm{C}\right)$ replacement medium ( $\mathrm{K}$ medium with $0 \mu \mathrm{M} \mathrm{NO}_{3}^{-}$and $20 \mu \mathrm{M} \mathrm{PO}_{4}{ }^{3-}$ ) was added daily to the bottom layer of the tank after the 14:00 h sample. To restore $\mathrm{N}$ to the bottom layer on Day 18, 1.5 I of replacement medium (concentrations adjusted to $5.0 \mathrm{mM} \mathrm{NO}_{3}{ }^{-}$and $0.6 \mathrm{mM} \mathrm{PO}_{4}{ }^{3-}$ ) was added below the thermocline. To restore $\mathrm{N}$ to the surface layer on
Day 21, 1.51 of the $\mathrm{N}$-rich replacement medium was added to the surface layer.

The experiment ran for $24 \mathrm{~d}$ with samples taken twice daily at 03:00 $\mathrm{h}$ (middle of the dark period) and 14:00 h (middle of the light period) for the first week. Once vertical migration of the cells began, sampling was increased to 4 times daily to include samples at the end of the light and dark periods, giving samples at $02: 00,07: 00,14: 00$, and 21:00 $\mathrm{h}$ for the remainder of the experiment. Due to a suspicion that $\mathrm{N}$ was recycling near the bottom of the tank (Heaney \& Eppley 1981), samples for $\mathrm{NH}_{4}{ }^{+}$analysis were collected, filtered (Whatman GFC) and frozen at 21:00 h on Day 17 of the experiment.

$\mathrm{N}$ starvation and resupply. The effects of $\mathrm{N}$ starvation and re-addition were examined with the use of a batch-culturing system consisting of four 15 I Nalgene polycarbonate culture vessels, each fitted with ports with individual tubes for bubbling, ventilation and sampling. Nitrate-poor $\mathrm{K}$ medium (10 1), containing $60 \mu \mathrm{M} \mathrm{NO}_{3}{ }^{-}$, was sterile-filtered $(0.2 \mu \mathrm{m}$ Gelman Culture Capsule filter) into 3 vessels (T1, T2 and T3), while $\mathrm{N}$-rich control media (10 1), containing $880 \mu \mathrm{M} \mathrm{NO}_{3}{ }^{-}$, was filtered into the fourth (C). All experimental media contained $30 \mu \mathrm{M} \mathrm{PO}_{4}{ }^{3-}$ to ensure that the cultures did not exhaust inorganic phosphorus.

Exponentially growing cells $\left(4.0 \times 10^{3}\right.$ cells $\left.\mathrm{ml}^{-1}\right)$ were inoculated into the 4 vessels and grown at a temperature of $15^{\circ} \mathrm{C}$ under a photosynthetically available quantum scalar irradiance of $140 \mu \mathrm{mol}$ quanta $\mathrm{m}^{-2} \mathrm{~s}^{-1}$ (provided by cool white fluorescent lamps and measured with a submersed Biospherical Instruments QSL$1004 \pi$ sensor) on a $14 \mathrm{~h}$ light: $10 \mathrm{~h}$ dark cycle with lights on at 08:00 and off at 22:00 h.

The experiment ran for $19 \mathrm{~d}$ during which samples were collected every second day beginning on Day 0 . On Day 14 of the experiment, after $N$ had been depleted in the $\mathrm{N}$-poor cultures for approximately $6 \mathrm{~d}$, nitrate was added back to the treatment cultures, elevating the concentration to $60 \mu \mathrm{M}$. Samples were taken from all cultures for cell counts, chl a concentration, fluorescence before and after DCMU addition, particulate $\mathrm{C}$ and $\mathrm{N}$, nutrient analysis $\left(\mathrm{NO}_{3}{ }^{-}, \mathrm{NO}_{2}{ }^{-}\right.$and $\mathrm{PO}_{4}{ }^{3-}$ ), and PSP toxin analysis. Samples were filtered and frozen for ammonium analysis on Days 6 and 18 to provide an indication of the extent of bacterial regeneration of $\mathrm{N}$.

N limitation during balanced growth. Semi-continuous cultures were established to investigate the effects of steady-state $N$ limitation on the toxin content of Alexandrium tamarense. Cultures were grown in 21 Erlenmeyer flasks containing $1 \mathrm{l}$ of medium under an irradiance and temperature regime identical to that of the $\mathrm{N}$-starvation experiment. Replicate cultures were grown under 2 nutrient regimes: $N$-replete control cul- 
tures containing $\mathrm{K}$ medium ( $880 \mu \mathrm{M} \mathrm{NO}_{3}{ }^{-}$) ( $\mathrm{R} 1$ and $\mathrm{R} 2$ ), and $\mathrm{N}$-limited treatment cultures containing $\mathrm{K}$ medium with $\mathrm{NO}_{3}{ }^{-}$adjusted to $60 \mu \mathrm{M}$ (L1 and L2). Replacement medium for the 2 treatments was filter sterilized (0.2 $\mathrm{mm}$ Gelman Culture Capsule filter) and stored in two 201 carboys situated above the cultures. The medium was added aseptically through a gravity-feed system.

The cultures were inoculated and left to grow for $13 \mathrm{~d}$ to a cell density of $4.5 \times 10^{3}$ cells $\mathrm{ml}^{-1}$ before dilutions were commenced. Dilutions were performed daily at 14:00 h by replacing the volume removed through sampling tubes with the replacement medium. Samples for cell density, chl a concentration (measured after a $24 \mathrm{~h}$ extraction), and fluorescence before and after DCMU addition were taken and analyzed daily at 14:00 h. Nitrogen-replete cultures were run comparably to turbidostats; equilibrium cell density was maintained by varying the dilutions between 20 and $30 \% \mathrm{~d}^{-1}$ depending on the previous days growth. The N-limited cultures were diluted by $15 \% \mathrm{~d}^{-1}$ thus dictating a $\mathrm{N}$-limited specific growth rate of $0.14 \mathrm{~d}^{-1}$. The cultures (with 1 exception discussed in results) were considered to be near steady state (i.e. balanced growth, day-to-day) after $29 \mathrm{~d}$, when cell density, chl a concentration, in vivo fluorescence, chl a per cell, fluorescence per cell, fluorescence per chlorophyll a and fluorescence before and after DCMU addition varied by $< \pm 20 \%$ about a constant mean for $10 \mathrm{~d}$. After this operationally defined steady state had been established, the experimental sampling was initiated and continued for an additional $14 \mathrm{~d}$. Daily samples were taken from each culture at 14:00 h for cell counts, chlorophyll a concentration, fluorescence before and after DCMU addition, particulate $\mathrm{C}$ and $\mathrm{N}$, nutrient analysis $\left(\mathrm{NO}_{3}^{-}, \mathrm{NO}_{2}^{-}\right.$and $\left.\mathrm{PO}_{4}{ }^{3-}\right)$ and PSP toxin analysis.

Analytical procedures. All discrete samples were analyzed identically for the 3 experiments. Cell concentrations were determined for triplicate $20 \mathrm{ml}$ samples (fixed with 1:1 paraformaldehyde:glutaraldehyde solution at a final concentration of $0.5 \%$ ) on a Coulter Multisizer II Particle Analyzer. Samples for the determination of chlorophyll were filtered (Whatman GF/C) and extracted in $10 \mathrm{ml}$ of $90 \%$ acetone at $-18^{\circ} \mathrm{C}$ for at least $24 \mathrm{~h}$. Chl a concentrations, corrected for pheopigments, were then determined using a Turner Designs fluorometer (Strickland \& Parsons 1972) calibrated with pure chl a (Sigma Chemical Co.). The cellular fluorescence capacity (CFC), a physiological index of relative photosynthetic efficiency (Vincent 1980), was calculated as $\left(F_{\mathrm{D}}-F\right) / F_{\mathrm{D}}$ where $F$ is the in vivo fluorescence and $F_{\mathrm{D}}$ is in vivo fluorescence after the addition of DCMU Samples (triplicate $5 \mathrm{ml}$ ) from each culture were dark adapted for a minimum of $30 \mathrm{~min}$ and fluorescence was measured before and $30 \mathrm{~s}$ after the addi- tion of $50 \mu \mathrm{J}$ of $3 \mathrm{mM}$ DCMU in ethanol. Samples of particulate material containing approximately $1 \mu \mathrm{g}$ chl (6 $\mu \mathrm{g} N$ ) were filtered on pre-ashed GF/C filters and stored until analysis for $\mathrm{C}$ and $\mathrm{N}$ on a Perkin Elmer $2400 \mathrm{CHN}$ Analyzer using acetanilide as a standard. Concentrations of $\mathrm{NO}_{3}{ }^{-}, \mathrm{NO}_{2}{ }^{-}$and $\mathrm{PO}_{4}{ }^{3-}$ were determined from filtered (GF/C) samples of culture medium by Technicon II Autoanalyzer (Grasshoff et al. 1976). Ammonium concentrations were determined colorimetrically according to Parsons et al. (1984).

Toxin analysis was performed by high performance liquid chromatography with fluorescence detection (HPLC-FD) according to minor modifications of the method of Oshima (1995). Toxins were resolved by reverse-phase chromatography using a silica-base column (Inertsil C8; $4.6 \mathrm{~mm}$ inner diam. $\times 150 \mathrm{~mm} ; 5 \mu \mathrm{m}$ particle size, GL Science). Three separate isocratic elutions were employed to separate the spectrum of PSP toxins at a flow rate of $0.8 \mathrm{~m}$ ] $\mathrm{min}^{-1}$. Toxin profiles were determined by duplicate injections of $10 \mu$ l of extracts (diluted 1:10 with $0.03 \mathrm{~N}$ acetic acid, as necessary) and toxins were quantified with certified external toxin standards (PSP-1) provided by the Marine Analytical Chemistry Standards Program (MACSP) of the Institute for Marine Biosciences. Mouse bioassay toxicity for the Alexandrium tamarense samples (in saxitoxin equivalents: STXeq) was calculated from the HPLC data as the sum of the individual toxin concentrations determined with reference to the peak area of the PSP1 external standard multiplied by toxin-specific conversion factors determined by Oshima (1995) using a standard mouse bioassay.

\section{RESULTS}

\section{Nitrate-stratified laboratory water column}

\section{Nutrients}

The tank experiment ran for $24 \mathrm{~d}$ and consisted of 5 phases characterized by the nitrate- $N$ availability in the water column: Phase I, pre-depletion; Phase II, N stratified; Phase III, N depleted; Phase IV, deep N restored; and Phase V, N replete (Fig. 2). Since the initial N:P ratio of the medium was $2.5: 1$ and because inorganic $P$ concentrations in the surface and bottom layers remained $>5.0 \mu \mathrm{M}$ for the entire experiment, $\mathrm{P}$ limitation was not considered to be a factor in this experiment (Goldman et al. 1979, McCarthy 1981). In addition, the $\mathrm{NO}_{2}{ }^{-}$concentration failed to increase to a level $>1.0 \mu \mathrm{M}$ and was not considered to be a significant source of $\mathrm{N}$

During Phase I (Days 0 to 6 ), the concentration of $\mathrm{N}$ in the top layer $(0$ to $20 \mathrm{~cm}$ ) decreased from its initial 
Nitrate Concentration $(\mu \mathrm{M})$

Phase I

Days 0-6

Phase II

Days 7-12

Phase IV

Days 18-20

Phase V

Days 21-23

(b) $\begin{array}{lllllll}200 & 10 & 20 & 30 & 40 & 50 & 60\end{array}$

(d)

(e)
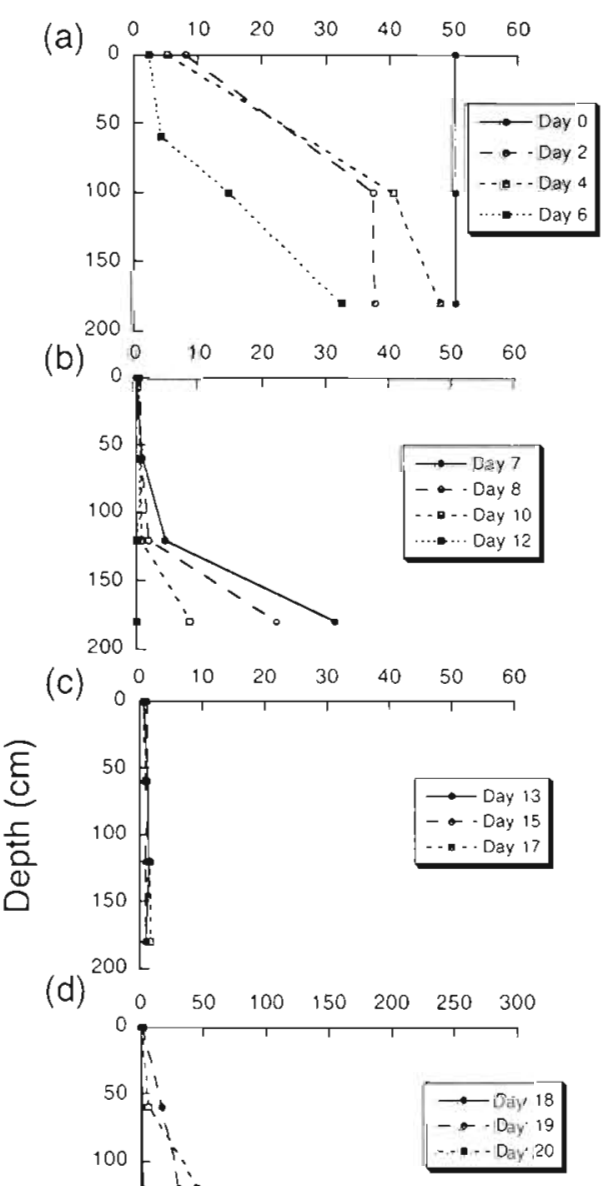

(f)

Chlorophyll a $\left(\mu \mathrm{gl}^{-1}\right)$

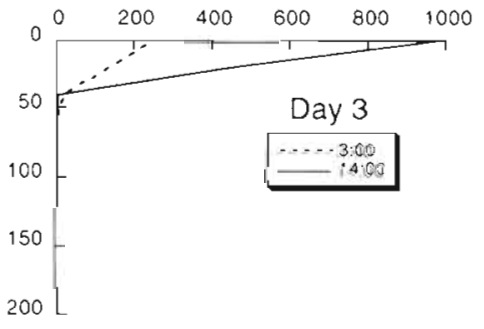

(g)

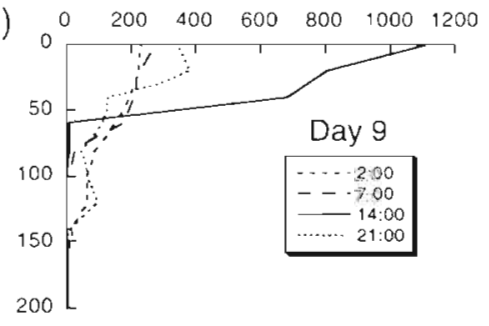

(h)

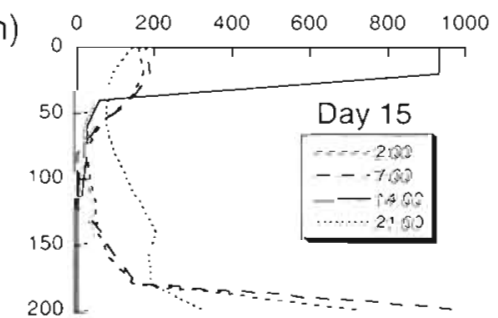

(i)
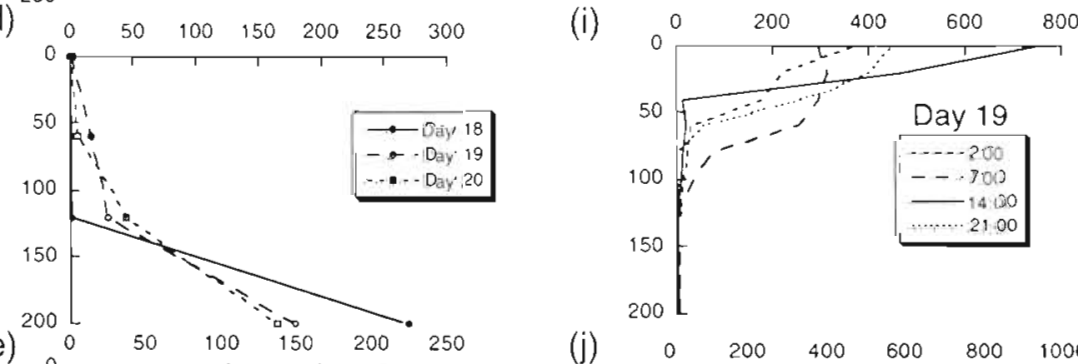

(j)

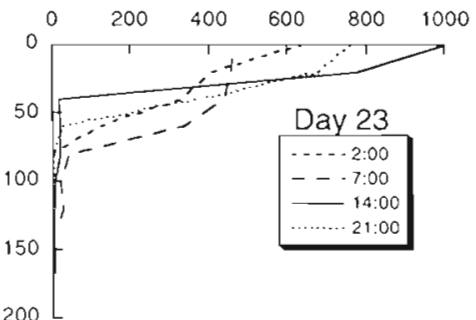

Fig. 2. Alexandrium tamarense. Relationship between the distributions of nitrate and chl a in the laboratory water column throughout the 5 phases of the experiment (organized vertically); numbers on vertical axis are depth in cm: (a) to (e) temporal shift in the nitrate concentration with depth (individual lines represent profiles taken at 14:00 h on different days); (f) to (j) profiles of cellular abundance displayed as chl a concentration (individual lines represent different points of the light:dark cycle of a single day)

value of $50.3 \mu \mathrm{M}$ to less than $1.0 \mu \mathrm{M}$, while $\mathrm{N}$ in the bottom layer $(180$ to $200 \mathrm{~cm})$ remained high $(>30 \mu \mathrm{M})$. In Phase II (Days 7 to 12), the bottom layer $\mathrm{N}$ decreased steadily until the $\mathrm{N}$ had declined to less than $1.0 \mu \mathrm{M}$. For the next $5 \mathrm{~d}$ (Phase III, Days 13 to 17) the $\mathrm{N}$ concentration in the entire water column remained at this very low level until 21:00 h on Day 17 (Phase IV), when
$\mathrm{N}$ was added back to the bottom layer after sampling Stratified nutrients were maintained from Days 18 to 20 (Phase IV). Nitrate was added to the surface layer after the 14:00 h sample on Day 20 (Phase V, Days 21 to 23). Discrete samples for $\mathrm{NH}_{4}{ }^{+}$analyses were taken on Day 17 (stored frozen for $4 \mathrm{mo}$ ) and revealed $\mathrm{NH}_{4}{ }^{+}$concentrations to be $0.25 \mu \mathrm{M}$ in the surface layer, $0.59 \mu \mathrm{M}$ 

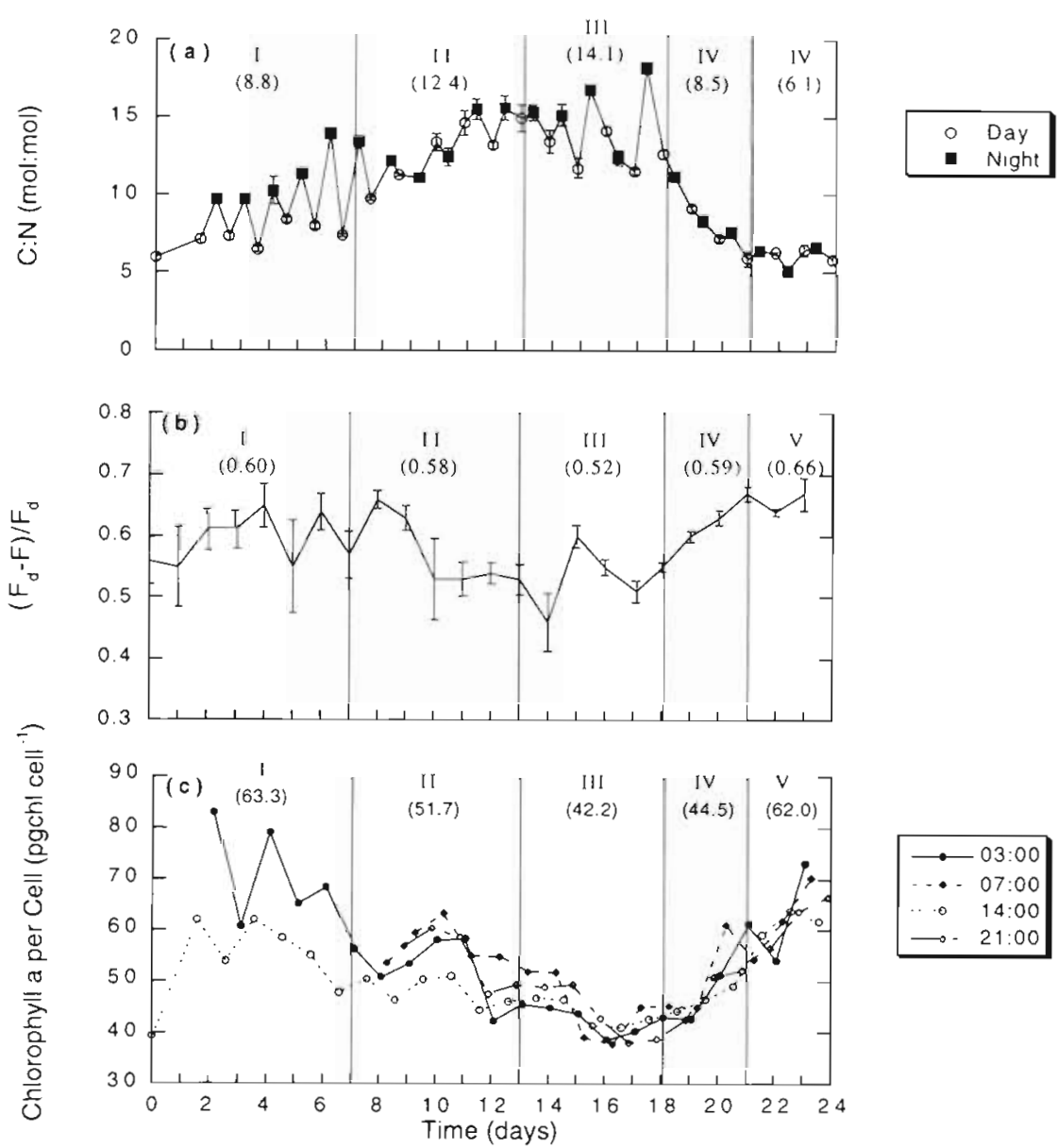

Fig. 3. Alexandrium tamarense. Changes in cellular nitrogen status during growth in the laboratory water column. (a) C:N ratio (0, samples taken at 14:00 h for the first week and at 21:00 h for the remainder; $\mathbf{m}$, samples taken at 3:00 $\mathrm{h}$ for the first week and at $7: 00 \mathrm{~h}$ for the remainder), (b) CFC ratio (taken daily at 14:00 h) and (c) chl a per cell (sampling times plotted as separate lines). The 5 phases (mean values in parentheses) of the experiment are labelled and delimited by the vertical lines. Error bars for $\mathrm{C}: \mathrm{N}$ and $\mathrm{CFC}$ are standard error of the mean $(n=3)$

at a $60 \mathrm{~cm}$ depth, $0.67 \mu \mathrm{M}$ at $100 \mathrm{~cm}$ depth and $2.50 \mu \mathrm{M}$ at $200 \mathrm{~cm}$, consistent with $\mathrm{N}$ regeneration in the deep layer (Heaney \& Eppley 1981). Regeneration could also have been occurring in the surface layer without accumulation. Nevertheless, any ammonium production occurring in the tank was insufficient to release the cells from $N$ stress.

The cellular ratio of $\mathrm{C}: \mathrm{N}$ and $\mathrm{chl}$ a per cell indicated the level of $N$ stress during various phases of the experiment (Fig. 3). The cellular chl a concentration decreases with increasing $N$ stress while the $C: N$ increases (Heaney \& Eppley 1981, Cleveland \& Perry 1987). Through the first 2 phases of the experiment, both the C:N ratio (increasing) and chl a per cell (decreasing) indicated a steadily decreasing $N$ content in the culture, which reached a low level during Phase III. These patterns were then reversed with the re-addition of $N$ to the bottom layer in Phase IV and continued through Phase $\mathrm{V}$. Another indicator of $\mathrm{N}$ stress is the CFC ratio (Vincent 1980), and although the CFC variations were less dramatic, the average values from the five phases indicate the same pattern and conclusions: the changes in $\mathrm{N}$ availability in the water column were sufficient to bring about related changes in cellular composition and physiological state (Cleveland \& Perry 1987).

\section{Migration}

During Phase I, when nitrate was available in the surface layer and the cells were $N$ replete, Alexandrium tamarense formed a concentrated surface layer during the light period which was maintained through the dark period (Fig. 2). Although the cells remained near the surface at night, profiles of fluorescence indicated that they were less tightly aggregated at the surface, with distributions extending to a slightly greater depth; significant fluorescence was not detected below $60 \mathrm{~cm}$. With the onset of $\mathrm{N}$ depletion at the surface (Phase II), the cells initiated a migration to the nitracline during the dark period. They still formed a surface layer during the light period; however, descent began before the end of the light period. Similarly, the cells initiated a return to the surface layer before the onset of the light 

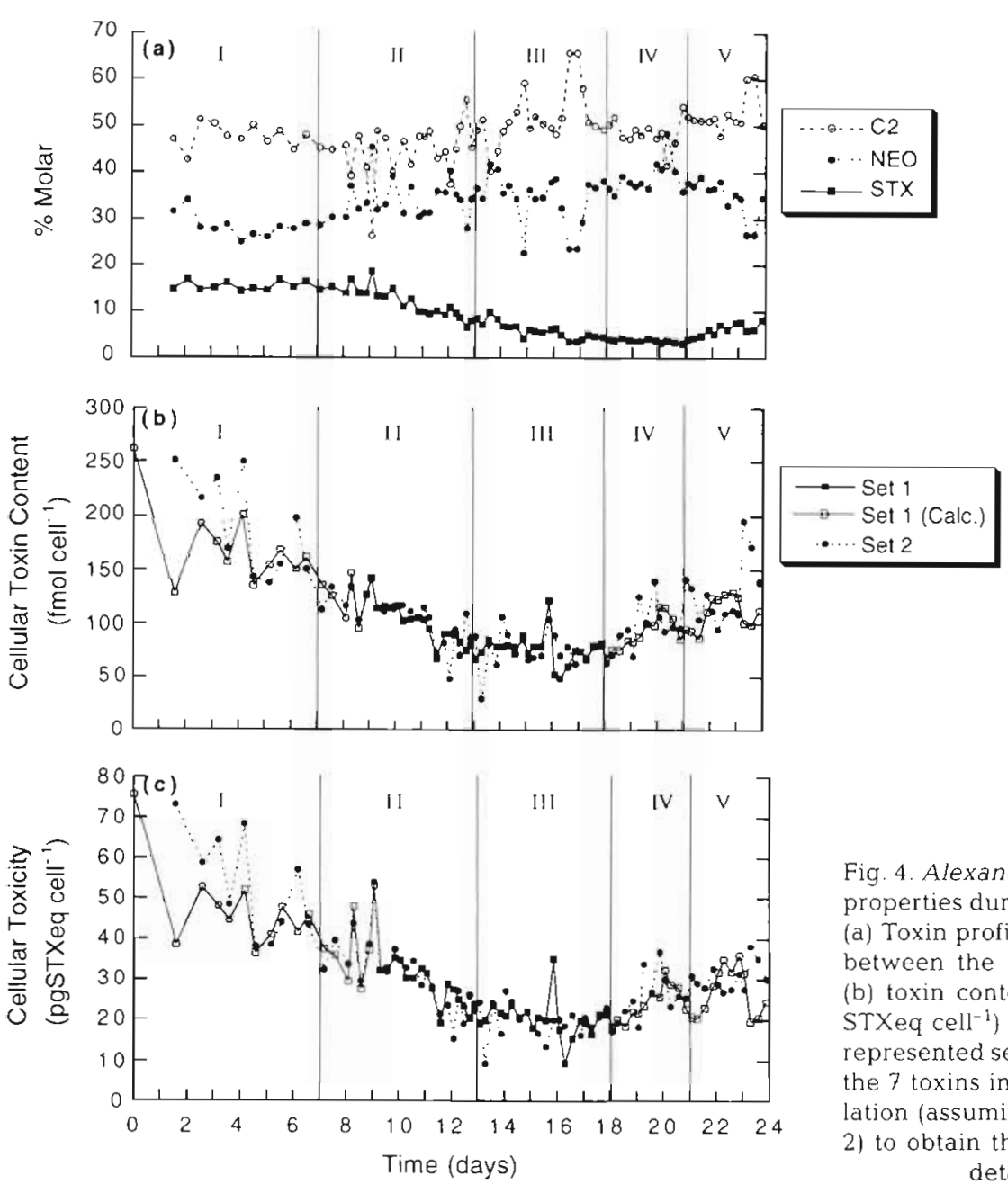

Fig. 4. Alexandrium tamarense. Changes in cellular toxin properties during growth in the laboratory water column (a) Toxin profile changes as depicted by the relationship between the molar percentages of the 3 major toxins, (b) toxin content (fmol toxin cell ${ }^{-1}$ ) and (c) toxicity (pg STXeq cell ${ }^{-1}$ ) of the cells over time. Aliquot samples are represented separately as sets 1 and 2; problems with 2 of the 7 toxins in certain samples of set 1 required a calculation (assuming the toxin profile was the same as in set 2) to obtain the missing values (see Maclntyre 1996 for detailed explanation of calculation)

period, indicating that migration was influenced by geotaxis in addition to positive phototaxis (Cullen \& Horrigan 1981, Häder et al. 1991). The dinoflagellates failed to form a well-defined nocturnal subsurface peak during Phase II; this may be a result of the relative proximity of the nitracline to the surface $(\sim 1 \mathrm{~m})$ and a relatively short duration spent at the nitracline. A nocturnal subsurface maximum was observed only when $N$ in the bottom layer was exhausted

During Phase III, when $N$ was depleted (some regenerated $\mathrm{N}$ may have been available at the bottom. see Heaney \& Eppley 1981), a much more dramatic migration was initiated as the cells crossed the thermocline, forming a maximum at the bottom of the column by mid-dark period which persisted until after the beginning of the light period (Fig. 2h). A surface layer was again formed by 14:00 $\mathrm{h}$ and dissipated before the onset of the dark period. This migration pattern resulted in the cells spending less time in the surface layer and penetrating deeper in the water column. As Phase IV was initiated by the addition of $\mathrm{N}$ to the bot- tom layer, the migration of cells became much less pronounced with a decreased nocturnal migration extending only to the nitracline at a depth of $\sim 120 \mathrm{~cm}$, a pattern similar to that of the previous $\mathrm{N}$-stratified period. With the addition of $\mathrm{N}$ to the surface layer at the beginning of the $N$-replete Phase $V$, the range of DVM did not change significantly from that of the previous phase.

Toxin

This highly toxic strain of Alexandrium tamarense was found to contain 9 of the nearly two dozen naturally occurring PSP toxins (Oshima 1995). The major toxins present, in order of relative abundance, were $\mathrm{C} 2, \mathrm{NEO}$ and STX. Other toxins found in minor abundance $(<10 \%$ of total toxins on a molar basis) were $C 1$, B1, GTX2, GTX3, GTX4, and dcGTX3. Although major changes in toxin profile (i.e. the relative abundances of the individual PSP toxins) were not demonstrated, a slight decrease in the molar percentage of STX was 

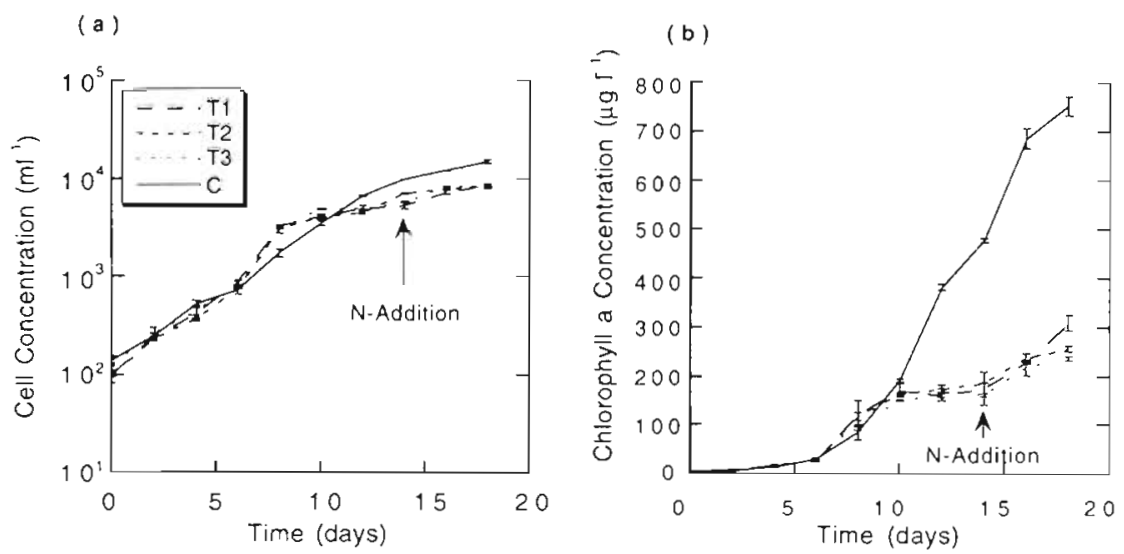

(c)

(d)
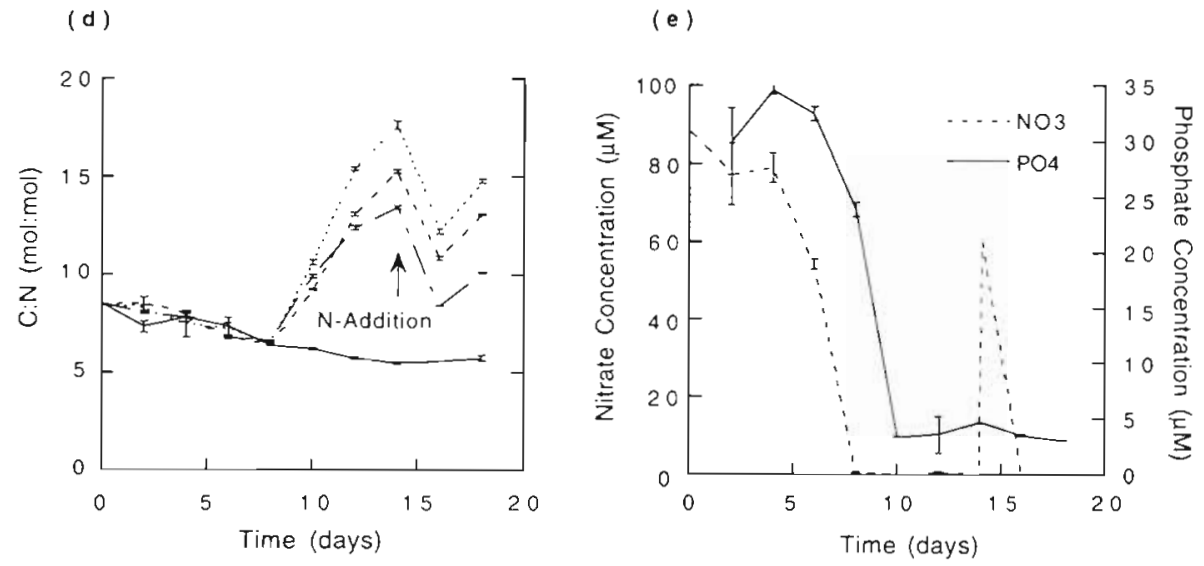

Fig. 5. Alexandrum tamarense. Growth curves (mean $\pm S E, n=3$ ) of batch cultures expressed as (a) cell concentration (log scale), and (b) chl a concentration (linear scale). Changes in the physiological status of the cultures with time: (c) CFC ratio and (d) C:N ratio. (e) Changes in the nutrient regime of the treatment cultures (nutrients were replete in the control cultures throughout the experiment)

observed in conjunction with increases in NEO and $\mathrm{C} 2$ during the period of lowest $\mathrm{N}$ availability (Phase III; Fig. 4a).

A steady decrease in the toxin content of cells was observed throughout the first 3 phases of the experiment in conjunction with the steadily decreasing concentrations of $\mathrm{N}$ in the tank. During Phase I, the toxin content of the cells decreased relative to the preinoculum cells (as measured on Day 0 ). With the depletion of surface-layer $\mathrm{N}$ and the onset of migration to the nitracline, toxin content of the cells decreased moderately through Phase II to reach a relatively constant low level which persisted through Phase III. However, during Phase IV, toxin content increased moderately to an intermediate level after nitrate was added to the deep layer. Subsequently, the toxin content and toxicity of the cells continued to increase after $\mathrm{N}$ was added back to the surface layer in Phase V.

Growth rates could not be calculated in the tank due to the heterogeneous distribution of the cells in the water column; thin layers or small patches could be missed, so an accurate measure of population density was not possible.

\section{$\mathrm{N}$ starvation and resupply}

The tank experiment demonstrated some responses of Alexandrium tamarense to nutrient starvation and resupply. Because the cells were capable of migration, however, the resultant light and temperature may have influenced any direct relationship between toxicity and nutrition. Therefore we also examined these effects using batch cultures in which temperature and irradiance were controlled.

\section{Growth}

All batch cultures grew at similar cell specific growth rates (calculated using logarithmic regressions of cell concentration data vs time) for the first $10 \mathrm{~d}$ of the experiment. The $\mathrm{N}$-limited treatment cultures ( $\mathrm{T} 1$, T2 and T3) grew at rates of $0.39\left(R^{2}=0.91\right), 0.39\left(R^{2}=\right.$ $0.91)$, and $0.38\left(R^{2}=0.97\right) \mathrm{d}^{-1}$ respectively between Days 0 and 10 . Growth rates subsequently decreased to an average of $0.08 \mathrm{~d}^{-1}$ between Days 10 and 14 , after nitrate concentration in the treatment media was depleted to $<1.0 \mu \mathrm{M}$ on Day 8 (Fig. 5). On Day 14 of 
the experiment, the nitrate concentration in the treatment cultures was increased to $60 \mu \mathrm{M}$, releasing the cultures from $\mathrm{N}$ starvation, resulting in a $38 \%$ increase in the cell concentration. The N-replete control culture (C) had a similar maximum growth rate of $0.32 \mathrm{~d}^{-1}\left(\mathrm{R}^{2}=0.99\right)$ (calculated between Days 0 and 10), before decreasing between Days 12 and 18 to $0.10 \mathrm{~d}^{-1}$ $\left(\mathrm{R}^{2}=0.97\right)$. This decline may have been a result of a decrease in the photosynthetically available irradiance as this strain of Alexandrium tamarense forms concentrated surface layers during the light period, thus further reducing the light field in already concentrated cultures (753 $\mu \mathrm{g} \mathrm{chl} \mathrm{l}^{-1}$ ). The reduction in growth rate was not likely to result from carbon limitation as the inorganic carbon content was maintained through aeration.

\section{Toxin}

The toxin composition of the cells in this experiment was similar to that reported in the tank experiment. The major toxins were found in the same order of abundance, C2, NEO and STX, while all the same minor toxins were found as well. The toxin profiles were similar between the treatment and control cultures and remained roughly constant throughout the experiment (Fig. 6a)

The total toxin content (nmol $\mathrm{ml}^{-1}$ ) of the treatment cultures increased through the $\mathrm{N}$ replete phase (Days 0 to 8 ) of the experiment and subsequently remained at an approximately constant level through $\mathrm{N}$ starvation, before increasing again with the re-addition of $\mathrm{N}$ on Day 14 (Fig. 6b). In contrast, the total toxin content of the control culture increased throughout the entire experiment. The toxin content (fmol cell ${ }^{-1}$ ) (Fig. 6c) and calculated toxicity (pg STXeq cell-1) of the cells in the treatment cultures were significantly lower (paired samples $t$-test, $p<0.01$ ) than those of the control culture when the treatment cultures were $N$ starved (Days 10 to 14 ).

\section{N limitation during balanced growth}

The tank and batch culture experiments both demonstrated toxin property changes in Alexandrium tamarense as they experienced unbalanced growth during $N$ starvation and resupply. Because unbalanced growth causes changes in cellular composition and physiology (Cullen et al. 1992), it is also important to
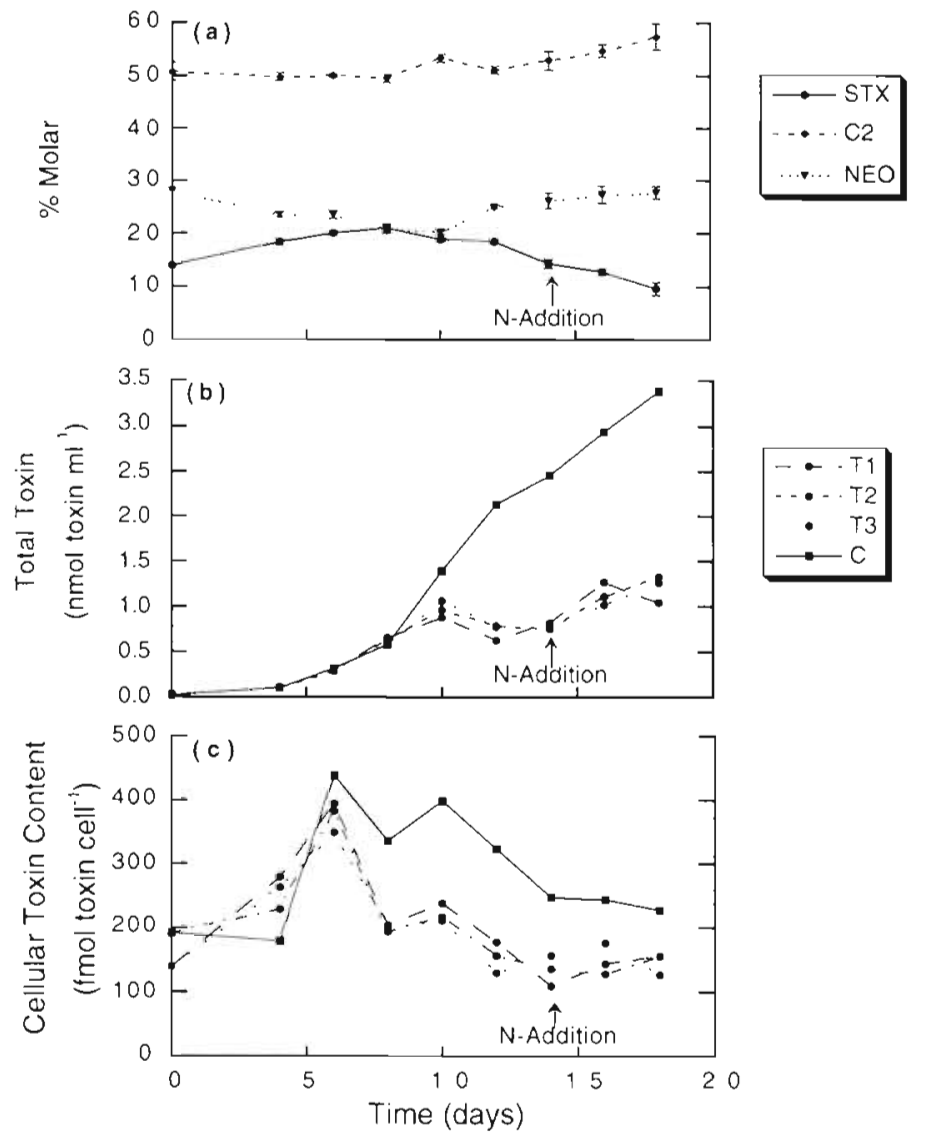

Fig. 6. Alexandnum tamarense. Changes in cellular toxin during growth in batch cultures. (a) Change in the molar \% of the major toxins in the treatment cultures over time (mean $\pm S E, n=3$ ). (b) Total PSP toxin content of the cultures (nmol toxin $\mathrm{ml}^{-1}$ ) and (c) cellular toxin content (fmol toxin cell ${ }^{-1}$ )

investigate the relationship between $\mathrm{N}$ limitation and toxin composition in a system that can provide conditions approximating balanced growth. Therefore, a semi-continuous system consisting of 2 contrasting levels of $\mathrm{N}$ availability was employed to investigate the effects of $N$ limitation on the toxin content of $A$. tamarense.

\section{Growth}

Cell specific growth rates $\left(\mu_{t}, \mathrm{~d}^{-1}\right)$ were calculated using the exponential growth equation:

$$
\mu_{i}=\frac{1}{\Delta t}\left(\ln \frac{N_{t} /(1-D)}{N_{t-\Delta t}}\right)
$$

where $N_{t}$ is the cell density (cells $\mathrm{ml}^{-1}$ ) at time $t$ (d), $N_{t-s}$ is the cell density (cells $\mathrm{ml}^{-1}$ ) at the previous time (here $\Delta t$ is $1 \mathrm{~d}$ ) and $D$ is the dilution rate (volume of fresh medium/total volume). Over the 2 wk experi- 

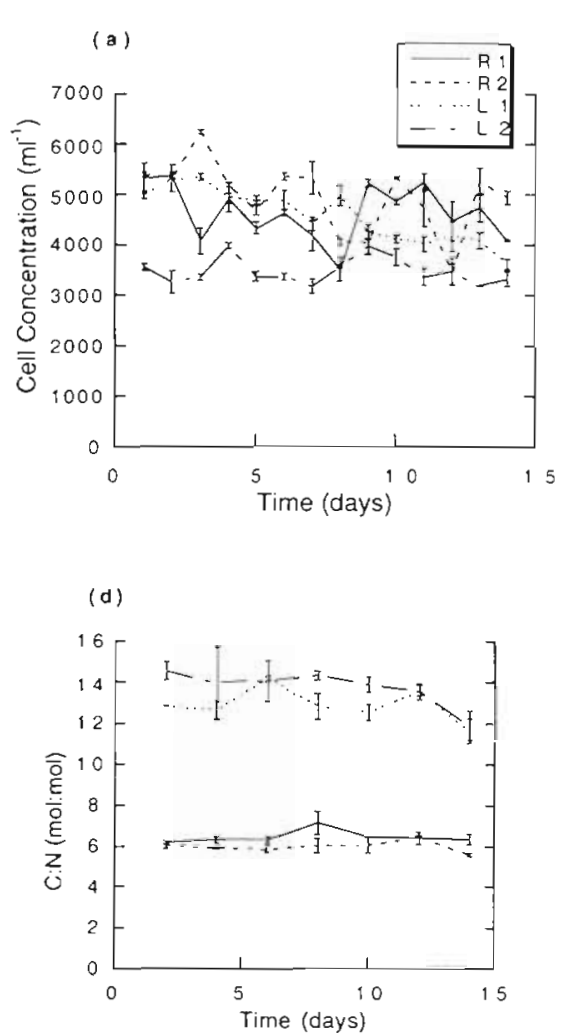

(b)

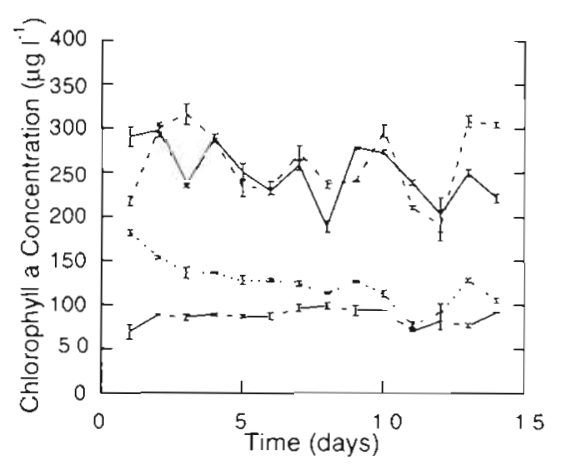

(e)

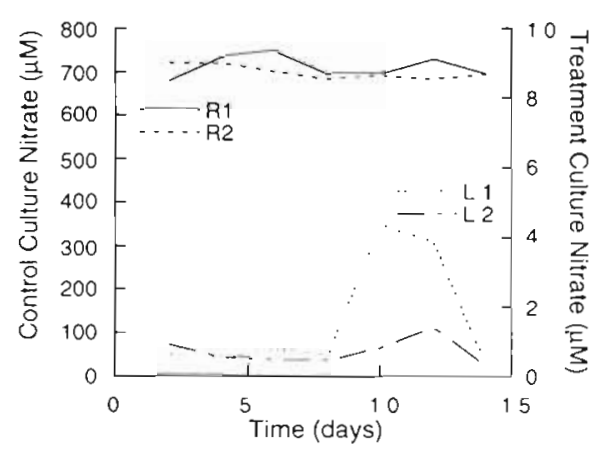

(c)

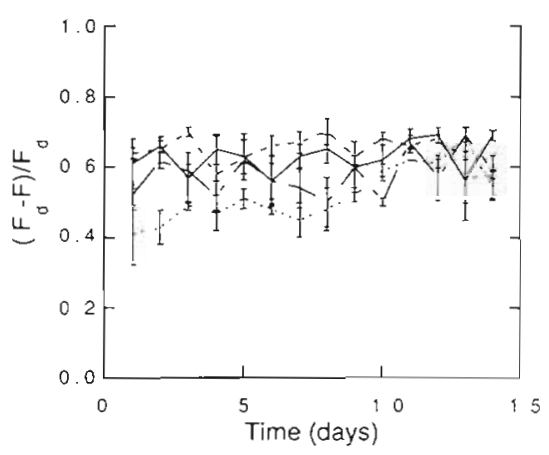

Fig. 7 Alexandrium tamarense. Characteristics in semi-continuous culture: (a) cell concentration, (b) chl a $1^{-1}$, (c) CFC ratio, and (d) C:N ratio for both the $\mathrm{N}$ replete $(R 1, R 2)$ and the $N$-limited cultures (L1, L2) (mean $\pm \mathrm{SE}, \mathrm{n}=$ 3). (e) Residual nitrate concentrations in both the $\mathrm{N}$-replete and $\mathrm{N}$-deplete culture media mental period, the $2 \mathrm{~N}$-replete cultures (R1 and R2) grew at average rates of 0.29 and $0.31 \mathrm{~d}^{-1}$, while the $N$ limited cultures (L1 and L2) were grown at lower average rates of 0.13 and $0.16 \mathrm{~d}^{-1}$ The average growth rate of $0.30 \mathrm{~d}^{-1}$ in the $\mathrm{N}$-replete cultures was similar to the maximum growth rates obtained in the batch-culture experiment (Fig. 5a), indicating that they maintained near maximum growth rates for ambient temperature and irradiance. Interestingly, culture L1, which had been restarted $11 \mathrm{~d}$ after the other cultures, was not fully equilibrated to the system when the experimental sampling was initiated despite showing signs of being in steady-state. Because cell density, CFC and carbon per chl a continued changing after chl a per cell, fluorescence per cell and fluorescence per chl a had equilibrated, it is apparent that the latter parameters alone are not adequate measures of steady state (Fig. 7). Therefore, these results demonstrate the need to consider as many parameters as possible when assessing a culture as steady state in order to get an accurate description of the true physiological status.

\section{Toxin}

The major toxins present in the semi-continuous cultures, under both $N$ regimes, were the same as found in the tank and N-starvation experiments, however, although $\mathrm{C} 2$ was again the most abundant followed by NEO and STX, they were found in different proportions between the $2 \mathrm{~N}$ regimes (Fig. 8). The major difference was the molar percentage of STX present in the cells (Fig. 8a). The N-replete cultures contained on average $16.2 \%$ STX in contrast to the $\mathrm{N}$-limited cultures which contained only $1.1 \%$ STX. The relative molar abundances of $\mathrm{C} 2$ and NEO were 55.0 and $24.5 \%$ respectively in the $\mathrm{N}$-replete cultures and 64.2 and $30.6 \%$ in the $\mathrm{N}$-limited cultures. Other differences in the profile were only slight. A 2-way repeated measures ANOVA of molar $\%$ revealed significant differences $(p \leq 0.011)$ in the relative abundances of the 3 major toxins between the $\mathrm{N}$-replete and $\mathrm{N}$-limited cultures. The data were arcsine transformed because the variance of a binomial distribution is a function of the mean (Sokal \& Rohlf 1981).

Toxin content per cell (fmol cell-1) and toxicity per cell (pg STXeq cell ${ }^{-1}$ ) remained at constant levels throughout the experiment for both the N-replete and $\mathrm{N}$-limited cultures and were higher under $\mathrm{N}$-replete conditions. The toxin content of the cells (fmol cell-1) was similar to those reported in the tank experiment, covering a similar range between $\mathrm{N}$ sufficiency and $\mathrm{N}$ deficiency (Fig. 9). 


\section{DISCUSSION}

Although it was previously demonstrated that a European strain of Alexandrium tamarense could migrate across steep pycnoclines (Rasmussen \& Richardson 1989) and thermoclines (Santos \& Carreto 1992), a marked diel pattern of vertical migration had yet to be confirmed in this toxin-producing species. This study demonstrates for the first time that. Alexandrium tamarense is capable of performing DVM across a steep thermocline to deep $\mathrm{N}$ pools when induced by low ambient $\mathrm{N}$ concentrations in surface waters. Although the toxin content of the cells was decreased during the $\mathrm{N}$-stratified phase relative to the $\mathrm{N}$-replete phase, A. tamarense was capable of producing PSP toxins from $\mathrm{N}$ acquired in the dark from the deep layers. In addition, toxin profile changes were confirmed and found to vary over a longer timescale than toxin content (Fig, 10). Most importantly, these results suggest that $A$. tamarense living in $\mathrm{N}$-poor coastal surface waters is likely capable of sustaining growth and toxin production through DVM to deep pools of nitrogen

\section{DVM behavior}

All aspects of the migratory behavior exhibited by Alexandrium tamarense in this experiment have been previously demonstrated individually in various dinoflagellates. However, collectively the pattern of DVM employed by A. tamarense under the present conditions is unique among the dinoflagellates studied to date. These findings reinforce the suggestions of Cullen (1985) and Cullen \& Maclntyre (unpubl.) that the contrasting nutritionally modified behaviors of coexisting migrating dinoflagellates result in distinct distributions in the water column and allow otherwise competing species to exploit individual niches. Thus, different combinations of otherwise common behaviors can result in the temporal and spatial separation of species, resulting in the diversification of niches.

Like vertical migration in other flagellates, DVM in Alexandrium tamarense is tightly correlated to the availability of $\mathrm{N}$ in the water column (Eppley et al. 1968, Cullen \& Horrigan 1981, Heaney \& Eppley 1981, Watanabe et al. 1991, Santos \& Carreto 1992), and in turn the nutritional status of the cells (Cullen 1985). When $N$ was available in the surface layer, cells did not undertake the nocturnal descent to the deep layer and as a result, did not initiate a DVM until surface-layer $N$ had been depleted. Subsequently, the extent of vertical migration increased as the nitracline deepened, consistent with nutritional control of migratory behavior. It is evident that DVM in A. tamarense is initiated and subsequently influenced by $N$ stress. Furthermore, although continued $N$ stress led to a prolonged stay in the deep layer, at no time did the cells lose their ability to migrate to the surface layer. Heterocapsa (Cachonina) niei (Eppley et al. 1968) also continued to migrate after $\mathrm{N}$ was depleted, although presumably, swimming ability would be precluded by a sufficiently prolonged $N$ starvation. Although the cells were obviously $N$ stressed during Phase III (Fig. 3), relatively high ammonium concentrations at the bottom of the tank from the regeneration of dead cells may also have 


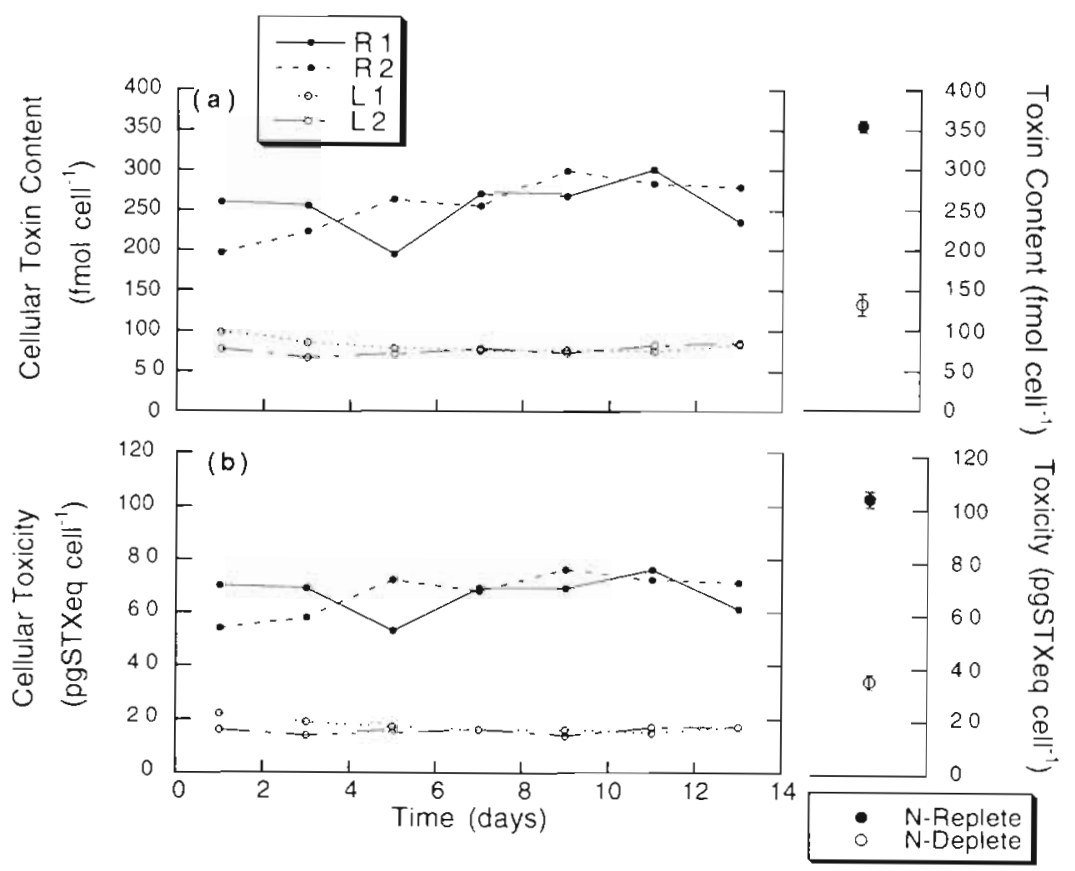

Fig. 9. Alexandrium tamarense. (a) PSP toxin content (fmol toxin cell ${ }^{-1}$ ) and (b) toxicity (pg STXeq cell ${ }^{-1}$ ) of both the $\mathrm{N}$-replete and $\mathrm{N}$-limited semı-continuous cultures with time. Each plot is accompanied by values (mean $\pm \mathrm{SE}, \mathrm{n}=3$ ) observed in the batch-culture experment. Representative $\mathrm{N}$-replete and $\mathrm{N}$ deplete values are from Day 6 and Day 14 ( 6 d after $N$ depletion) of the batchculture experiment respectively

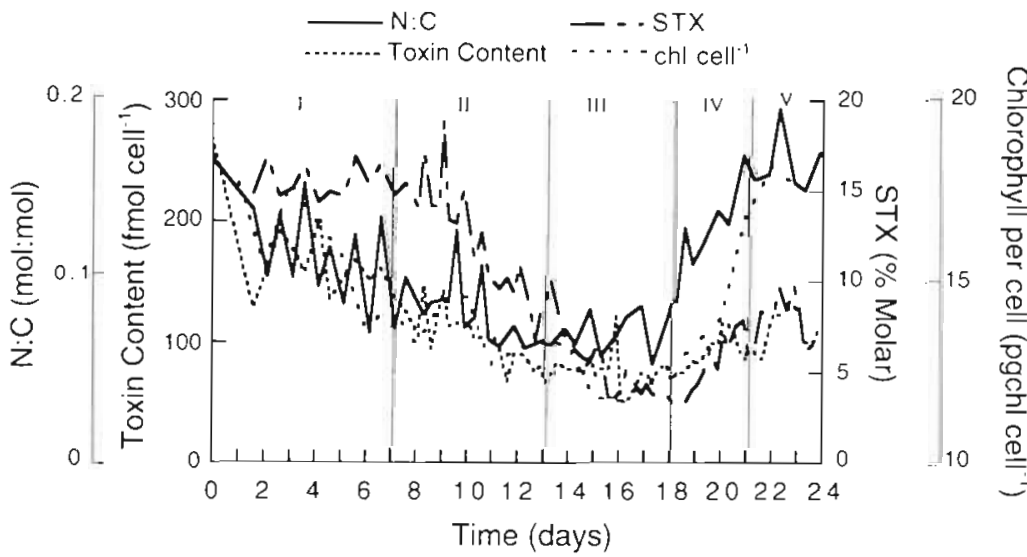

Fig. 10. Alexandrium tamarense. The N:C ratio, cellular toxin content, cellular chl $a_{1}$ and toxin profile (\% molar STX) in the laboratory water column over the 5 phases of the experiment. The C:N ratio was inverted for this figure to clarify the relationship between the $\mathrm{N}$ status of the cell and the toxin characteristics. This demonstrates the different time scales for change required by the various parameters. The 5 phases of the experiment are delimited by the vertical lines has also been reported to occur in Heterocapsa niei (UTEX LB1564 Cullen et al. 1985) in bright light, it is in stark contrast to Lingulodinium polyedrum (= Gonyaulax polyedra) (Heaney \& Eppley 1981), Heterocapsa (Cachonina) niei (Eppley et al. 1968), Gymnodinium sanguineum (splendens) (Cullen \& Horrigan 1981) and Prorocentrum micans (Kamykowski 1981), all of which continue migrating in the presence of $\mathrm{N}$ throughout the water column. One possibility for the contrasting responses to surface layer $N$ could be the relatively different $N$ concentrations employed. Whereas in the present experiment the surfacelayer nitrate concentration was elevated to well above $10 \mu \mathrm{M}$, the other studies employed lesser concentrations. It may be that, although $N$ was available throughout the water column in the other studies, it was still present in a limiting supply, resulting in a continued migration. Another possibility is that differences in the photon flux density resulted in the contrasting behavioral patterns. However, contrasting results could also represent interspecific or interclonal behavioral differences. Presumably, natural selection asserts that cells will naturally adopt the behavior which complements their specific physiological adaptations.

In the present study, apparent phototactic behavior was abserved as the cells aggregated at the maximum available irradiance through all levels of $\mathrm{N}$ availability in the tank. However, during Phase II of the experiment, when $N$ was available in the deep layer only, the cells initiated their descent before the lights were extinguished and returned to the surface prior to the onset of the light period. Therefore, while the cells appeared to be phototactic, N stress induced a nocturnal migration to deep $\mathrm{N}$ pools whose timing was linked to a diel rhythm. Such diel rhythms, which enabled the cells to maintain a daily migration to the surface layer (Heaney \& Eppley 1981).

Vertical migrations did cease, however, when $\mathrm{N}$ was available in the surface layer. Although this behavior have been reported also in Gymnodinium sanguineum (splendens) (Cullen \& Horrigan 1981), Prorocentrum micans (Kamykowski 1981), Ceratium furca and Lingulodinium polyedrum (= Gonyaulax polyedra) 
(Heaney \& Eppley 1981), indicate that DVM in various species is not purely a result of phototaxis but is also physiologically tuned to changes in the immediate environmental conditions (Kamykowski 1995). In addition, because migrations are accomplished in complete darkness, geotaxis is also likely involved (Cullen \& Horrigan 1981, Häder et al. 1991). Furthermore, the diel rhythm exhibited by Alexandrium tamarense in the present study was not a static mechanism, as the timing of the migrations was altered by increasing $\mathrm{N}$ stress, allowing the cells to spend an increasing proportion of time in the deep layer as the lack of $\mathrm{N}$ persisted.

During the final phase (Phase $V$ ), when $N$ was again replete throughout the tank, the cells did not change their migration pattern significantly from the previous $\mathrm{N}$-stratified phase (Phase IV). This may have occurred if the cells had not fully recovered from $\mathrm{N}$-stress by the initiation of Phase V. Nevertheless, these results indicate that migratory behavior in Alexandrium tamarense is induced by a lack of available $\mathrm{N}$ in the surface layer and that the timing of the migrations is further influenced by $N$ stress. Thus DVM in $A$. tamarense is a complex behavior induced by $N$ stress and influenced by factors such as diel rhythms and geotaxis which are further influenced by $N$ nutrition. Such flexible behavioral adaptations enable $A$. tamarense to enhance its growth potential in an otherwise nutrient-poor environment.

\section{Toxin physiology}

The main focus of this experiment was to compare the toxin characteristics of Alexandrium tamarense in a $\mathrm{N}$-stratified regime to those of $\mathrm{N}$-starved and $\mathrm{N}$-limited cells. The results indicate that, although cells living in a $\mathrm{N}$-stratified water column were less toxic than $\mathrm{N}$-replete cells, they were able to maintain (Phase II) or attain (Phase IV) a moderate level of toxicity through DVM (Fig. 4b, c). Thus A. tamarense which appear in $\mathrm{N}$-depleted surface waters are capable of producing PSP toxins utilizing $\mathrm{N}$ acquired from deep pools. However, because a diel pattern of toxin production could not be discerned from our data, the timing of the toxin production in the vertically migrating cells could not be determined. As a result, it is not known if the toxins were produced at night or if $\mathrm{N}$ was stored for toxin production during the day. Although photosynthesis has previously been hypothesized to play a crucial role in the production of PSP toxins (Ogata et al. 1987, Scarratt 1994), it is possible that toxins could be produced at depth in the absence of light. During the light period, the storage of carbohydrate should be stimulated in dinoflagellates in $\mathrm{N}$-stratified waters by high irradiance and the lack of available $\mathrm{N}$ in the surface layer (Cullen 1985). As the cells migrate to deep nutrient pools at night, stored photosynthetic products are available for utilization in the uptake and assimilation of $\mathrm{N}$. Although $\mathrm{N}$ uptake is generally coupled with photosynthesis, the process can still be carried out in the absence of light (Harrison 1975, Cuhel et al. 1984, Paasche et al. 1984). Our results suggest that while toxin production may be more efficient when coupled with photosynthesis, this process may be accomplished to a moderate degree in the absence of light through the utilization of stored photosynthate.

The $N$-limited semi-continuous cultures described here and in Anderson et al. (1990a) demonstrated that toxin profile changes do occur in Alexandrium spp. when cells remain viable and adapt to a limiting supply of N. Anderson et al. (1990a) also found dramatic differences in the toxin profiles in semi-continuous cultures of Alexandrium fundyense having different degrees of $\mathrm{N}$ limitation and reported similar shifts in the proportions of STX and C2. These are interesting results as notable changes in toxin profile have not been reported for actively growing, non-axenic batch cultures (Boyer et al. 1987, Cembella et al. 1987, Ogata et al. 1987. Flynn et al. 1994)

The toxin profile changes in the N-starved batch cultures and in the tank culture were much less pronounced than in the semi-continuous cultures. Differences between the contrasting culturing systems and growth modes are believed to be responsible for the conflicting results. Most obvious is the difference in the duration of the $\mathrm{N}$-stressed period of each experiment. It can be argued that the $\mathrm{N}$-stressed period of a batch culture is of insufficient duration to allow changes in the toxin profile to occur. However, the $\mathrm{N}$-stress period was long enough to induce dramatic changes in cellular toxin content, chl a concentration and the overall $\mathrm{C}: \mathrm{N}$ ratio. Alternatively, the $\mathrm{N}$-stress period in the tank was much longer, and a trend can be observed when the toxin properties are plotted with $\mathrm{N}: \mathrm{C}$ and chl a per cell (from Fig. 3), with toxin profile changing more slowly than toxin content (Fig. 10). These time-dependent responses relate to the fundamental differences between the physiological responses of cells to $\mathrm{N}$ limitation, $\mathrm{N}$ starvation and $\mathrm{N}$ stratification (Anderson et al. 1990a) That is, the semi-continuous cultures exhibited more pronounced toxin profile changes because a limiting supply of $\mathrm{N}$ enabled the cells to continue growing through and beyond the initial adjustment period, resulting in N-limited, steady-state cells with a different cellular composition than N-starved cells. The N-stratified phase of the tank experiment allowed cells a short period to adjust to an increasingly limited $\mathrm{N}$ supply, and thus a definite trend in toxin profile changes is easily observed. It is becoming increasingly clear that, al- 
though toxin profile changes do not correlate with cellular $\mathrm{N}$ status as closely as other indicators of $\mathrm{N}$ stress, such as C:N, chl a per cell and toxin content (Fig 10), changes do occur if cells are given sufficient opportunity to adjust to $N$ stress. Potential benefits of such toxin profile changes are discussed in Macintyre (1996).

A review of the toxin results from the 3 experiments reveals that the ranges of toxin content values were slightly different between the 3 experiments, with the highest toxicities recorded during unbalanced growth in the batch cultures (Figs. 4, 6 \& 9). The N-replete, semi-continuous cultures, which contained $\mathrm{N}$ concentrations similar to those of the batch cultures, did not attain the same level of toxicity even after a prolonged exposure to this extremely high $N$ supply. Previous batch culture studies have demonstrated that toxin content in dinoflagellates is a function of the 2 rates of toxin production and cell division (Boyer et al. 1987, Anderson 1990b, Flynn et al. 1994). During unbalanced growth, relative changes in the rates of toxin production and cell division result in changes in the cellular toxin content. The higher toxin values attained in the batch cultures studied here resulted from an initial lag in cell division which did not occur in toxin production. Therefore, when presented with high $\mathrm{N}$ availability and a reduced rate of cell division either initially due to an inoculation shock or subsequently due to $P$ limitation (Anderson et al. 1990b, Flynn et al. 1994), cells in unbalanced growth reach toxic levels which are not seen in balanced systems. Consequently, the most toxic cells found in nature will be those in which cell division is inhibited by a factor which does not also limit toxin production.

\section{Ecological implications}

Alexandrium spp. have been known to cause shellfish toxicity in various regions of the world (Sakshaug \& Jensen 1971, Anderson \& Stolzenbach 1985, Iwasaki 1989, Esteves et al. 1992, Rensel 1993). Although physical forcing factors, either working alone or in combination with diel migrations, have been implicated in the formation of dense patches of Alexandrium spp. (Hartwell 1975, Seliger et al. 1979), the results presented here demonstrate that these organisms are also capable of forming dense surface layers in the absence of physical forcing factors in stratified coastal waters characteristic of dinoflagellate bloom conditions. Although toxin content in toxic dinoflagellates is considered to be directly related to the ambient $N$ concentration, through behavioral adaptations, $A$. tamarense is capable of exploiting deep $N$ sources to sustain growth and produce PSP toxins. Thus N-depleted coastal surface waters may still harbor significant pop- ulations of toxic dinoflagellates if the waters are stratified and a $N$ source is present within the range of the daily migrational capabilities of the cells.

The use of contrasting experimental systems in the present study of the relationship between $\mathrm{N}$ availability and toxicity has provided new insights into the ecology of toxic dinoflagellates. While batch cultures simulated a bloom, decline and nutrient pulse, the semi-continuous experiment was designed to simulate a steady-state system such as is found in tightly coupled systems. In contrast, the tank experiment provides a spatial dimension, making it more relevant to stratified coastal ecosystems. Considering the results from all 3 systems, we can conclude that cells in $N$ stratified coastal waters may be capable of maintaining a moderate level of toxicity, while the highest toxicities on a cellular basis will occur during unbalanced growth when the rate of cell division is inhibited relative to toxin production. Therefore, scenarios which produce highly toxic cells by reduction of cell division may not be as important to shellfish toxification as those which favor a dinoflagellate bloom of somewhat less toxic cells. While the toxicity of individual cells may vary only by a factor of 2 or 3 over varying degrees of $N$ availability, cell numbers may increase by orders of magnitude during a bloom. Therefore, stable, stratified, $\mathrm{N}$-limited coastal waters should be considered as potentially favorable for shellfish contamination.

Although a toxic dinoflagellate bloom or 'red tide' may be an obvious threat, it is also likely that less concentrated populations could cause significant shellfish contamination if the population can persist for a sufficient period of time (Sakshaug \& Jensen 1971). The Bay of Fundy (Prakash 1967), the St. Lawrence estuary (Cembella et al. 1988a, b) and the Gulf of Maine (Franks \& Anderson 1992a, b) all frequently experience toxic shellfish incidents resulting from Alexandrium spp. in the absence of dense aggregations of cells. Thus while vertical migration behavior may enable a population to bloom when conditions become favorable, such behavior could also conceivably assist a population in maintaining lower concentrations of cells during less favorable conditions.

Although cellular toxicity and population density are commonly considered as important factors involved in PSP toxin accumulation in shellfish, variation in toxicity between species and strains (up to 1000x; Cembella et al. 1987) necessitates that the specific toxicity of a species or strain should be first considered within a given geographical area. Although the observed level of toxicity of cells during $\mathrm{N}$-stratified conditions was lower relative to that during $N$-replete conditions, in absolute terms it is still extremely toxic relative to other strains and species of toxic dinoflagellates (Cembella et al. 1987, 1988a) 
We conclude that diel vertical migration by Alexandrium tamarense is influenced by the availability of $\mathrm{N}$. This nutritionally mediated behavior can enable a population to persist in stratified coastal waters for longer periods than would otherwise be possible. Consequently, the contamination of shellfish would be enhanced by the ability of toxic dinoflagellates to modify behavior in response to changes in the distribution of nutrients.

Acknowledgements. Support for this study was provided by NSERC Canada. We thank Gary Maillet for his extensive assistance with the intensive sampling period of the tank experiment as well as much additional technical help and advice. Thanks to Joe Uher, who provided technical assistance with the HPLC analyses using standards provided by the MACS Program of the Institute for Marine Biosciences, NRC. Thanks also to 4 anonymous reviewers who provided prompt, perceptive and constructive reviews. Finally, thanks to Glen Harrison of The Bedford Institute of Oceanography who provided facilities for the CHN analyses. This is CEOTR publication No. 008 and NRC No. 39731

\section{LITERATURE CITED}

Anderson DM (1990) Toxin variability in Alexandrum species. In: Granéli E, Sundström B, Elder L, Anderson DM (eds) Toxic marine phytoplankton. Elsevier, Amsterdam. p 41-51

Anderson DM, Kulis DM. Sullivan JJ, Hall S (1990a) Toxin composition variations of the dinoflagellate Alexandrium fundyense. Toxicon 28(8):885-893

Anderson DM, Kulis DM, Sullivan JJ, Hall S, Lee C (1990b) Dynamics and physiology of saxitoxin production by the dinoflagellates Alexandrium spp. Mar Biol 104:511-524

Anderson DM, Stolzenbach KD (1985) Selective retention of two dinoflagellates in a well-mixed estuarine embayment: the importance of diel vertical migration and surface avoidance. Mar Ecol Prog Ser 25:39-50

Blasco D (1978) Observations on the diel migration of marine dinoflagellates of the Baja California Coast. Mar Biol 46: $41-47$

Boczar BA, Beitler MK, Liston J, Sullivan JJ, Cottolico RA (1988) Paralytic shellfish toxins in Protogonyaulax tamarensis and Protogonyaulax catenella in axemic culture. Plant Physiol 88:1285-1290

Boekel WHM, Hansen FC, Riegman R, Bak RPM (1992) Lysisinduced decline of a Phaeocystis spring bloom and coupling with the microbial foodweb. Mar Ecol Prog Ser 81: $269-276$

Boyer GL, Sullivan JJ, Anderson RJ, Harrison PJ, Taylor FJR (1987) Effects of nutrient limitation on toxin production and composition in the marine dinoflagellate Protogonyaulax tamarensis. Mar Biol 96:123-128

Busto CE, Carretto JI, Benavides HR, Sancho H, Colleoni DC, Carignan MO, Fernandez A (1993) Paralytic shellfish toxicity in the Argentine Sea, 1990: an extraordinary year. In: Smayda TJ, Shimizu Y (eds) Toxic phytoplankton blooms in the sea. Elsevier, Amsterdam, p 229-233

Carretto JI, Carrigan MO, Daleo G, De Marco SG (1990) Occurrence of mycosporine-like amino acids in the redtide dinoflagellate Alexandrium excavatum: UV-photoprotective compounds? J Plankton Res 12(5):909-921

Cembella AD, Sullivan JJ, Boyer GL, Taylor FJR, Andersen RJ (1987) Variation in paralytic shellfish toxin composition within the Protogonyaulax tamarensis/catenella species complex; red tide dinoflagellates. Biochem Syst Ecol 15(2): $171-186$

Cembella AD, Therriault JC (1989) Population dynamics and toxin composition of Protogonyaulax tamarensis from the St. Lawrence Estuary. In: Okaich $T$, Anderson DM, Nemoto T (eds) Red tides: biology, environmental science and toxicology. Elsevier. Amsterdam, p 81-84

Cembella AD, Therriault JC, Beland P (1988a) Toxicity of cultured isolates and natural populations of Protogonyaulax tamarensis from the St. Lawrence Estuary. J Shellfish Res $7(4): 611-621$

Cembella AD, Turgeon J, Therriault JC, Beland P (1988b) Spatial distribution of Protogonyaulax tamarensis resting cysts in nearshore sediments along the north coast of the lower St. Lawrence Estuary. J Shellfish Res 7(4):597-609

Cleveland JS, Perry MJ (1987) Quantum yield, relative specific absorption and fluorescence in nitrogen-limited Chaetoceros gracilis. Mar Biol 94:489-497

Cuhel RL, Ortner PB, Lean DRS (1984) Night synthesis of protein by algae. Limnol Oceanogr 29(4):731-744

Cullen JJ (1985) Diel vertical migration by dinoflagellates: roles of carbohydrate metabolism and behavioral flexibility. Contrib Mar Sci (Suppl) 27:135-152

Cullen JJ, Horrigan SG (1981) Effects of nitrate on the diurnal vertical migration, carbon to nitrogen ratio, and the photosynthetic capacity of the dinoflagellate Gymnodinium splendens. Mar Biol 62:81-89

Cullen JJ, Mingyuan Z, Davis RF, Pierson DC (1985) Vertical migration, carbohydrate synthesis, and nocturnal nitrate uptake during growth of Heterocapsa niei in a laboratory water column. In: Anderson DM, White AW, Baden DG (eds) Toxic Dinoflagellates. Elsevier, Amsterdam, p $189-194$

Cullen JJ, Yang X, Macintyre HL (1992) Nutrient limitation of marine photosynthesis. In: Falkowski PG, Woodhead AD (eds) Primary productivity and biogeochemical cycles in the sea. Plenum Press, New York, p 69-88

Eppley RW, Harrison WG (1975) Physiological ecology of Gonyaulax polyedra: a red tide dinoflagellate of southern California. In: LoCicero VR (ed) Proc 1st Int Conf Toxic Dinoflagellate Blooms. Massachussetts Science and Technology Foundation, Wakefield, MA, p 11-22

Eppley RW, Holm-Hansen O. Strickland JD (1968) Some observations on the vertical migration of dinoflagellates. J Phycol 4:333-340

Esteves JL, Santinelli N, Sastre V, Diaz R, Rivas O (1992) A toxic dinoflagellate bloom and PSP production associated with upwelling in Golfo Nuevo, Patagonia, Argentina. Hydrobiologia 242:115-122

Flynn K, Franco JM, Fernandez P, Reguera B, Zapata M. Wood G, Flynn K (1994) Changes in toxin content, biomass and pigments of the dinoflagellate Alexandrium minutum during nutrogen refeeding and growth into nitrogen or phosphorus stress. Mar Ecol Prog Ser 111:99-109

Fraga F, Perez FF, Figueiras FG, Rios AF (1992) Stouchiometric variations of $\mathrm{N}, \mathrm{P}, \mathrm{C}$ and $\mathrm{O}_{2}$ during a Gymnodinium catenatum red tide and their interpretation. Mar Ecol Prog Ser $87(1-2): 123-134$

Franks PJS, Anderson DM (1992a) Alongshore transport of a toxic phytoplankton bloom in a buoyancy current: Alexandrium tamarense in the Gulf of Maine. Mar Biol 112: $153-164$

Franks PJS, Anderson DM (1992b) Toxic phytoplankton blooms in the southwestern Gulf of Maine: testing hypotheses of physical control using historical data. Mar Biol 112:165-174 
Goldman JC, McCarthy JJ, Peavey DG (1979) Growth rate influence on the chemical composition of phytoplankton in oceanic waters. Nature 279:210-215

Grasshoff K, Ehrhardt M, Kremling K (1976). Methods of seawater analysis. Verlag Chemie, Weinheim, p 125-157

Häder DP, Liu SM, Kreuzberg K (1991) Orientation of the photosynthetic flagellate, Peridinium gatunense, in hypergravity. Curr Microbiol 22:165-172

Harrison PJ (1975) Nitrate metabolism of the red tide dinoflagellate Gonyaulax polyedra Stein. J Exp Mar Biol Ecol 21 199-209

Hartwell AD (1975) Hydrographic factors affecting the distributions and movement of toxic dinoflagellates in the western Gulf of Maine. In: LoCicero VR (ed) Proc 1st Int Conf Toxic Dinoflagellate Blooms. Massachussetts Science and Technology Foundation, Wakefield, MA, p 47-68

Heaney SI, Eppley RW (1981) Light, temperature and nitrogen as interacting factors affecting diel vertical migrations of dinoflagellates in culture. J Plankton Res 3(2):331-344

Holmes RW, Williams PM, Eppley RW (1967) Red water in La Jolla Bay, 1964-1966. Limnol Oceanogr 12:503-512

Iwasaki H (1989) Recent progress of red tide studies in Japan: an overview. In: Okaichi T, Anderson DM, Nemoto T (eds) Red tides: biology, environmental science and toxicology. Elsevier, Amsterdam, p 3-9

Kamykowski D (1981) Laboratory experiments on the diurnal vertical migration of marine dinoflagellates through temperature gradients. Mar Biol 62:57-64

Kamykowski D (1995) Trajectories of autotrophic marine dinoflagellates. J Phycol 31:200-208

Keller MD, Selvin RC, Claus W, Guillard RRL (1987) Media for the culture of oceanic ultraplankton. J Phycol 23: $633-638$

Kiefer DA, Lasker R (1975) Two blooms of Gymnodinium splendens, an unarmored dinoflagellate. Fish Bull US 73 : 675-678

Macintyre JG (1996) Vertical migration and toxicity in Alexandrium tamarense. MSc thesis, Dalhousie University, Halifax

McCarthy JJ (1981) The kinetics of nutrient utilization. In: Platt T (ed) Physiological bases of phytoplankton ecology Can Bull Fish Aquat Sci 210:211-233

Ogata T, Ishimaru T, Kodama M (1987) Effect of water temperature and light intensity on growth rate and toxicity change in Protogonyaulax tamarensis. Mar Biol 95: $217-220$

Oshima Y (1995) Post-column derivatization HPLC methods for paralytic shellfısh poisons. In: Hallegraeff GM, Anderson DM. Cembella AD (eds) Manual on harmful marine microalgae, IOC manuals and guides No. 33. UNESCO, Paris, p $81-94$

This article was submitted to the editor
Paasche E, Bryceson I, Tangen K (1984) Interspecific variation in dark nitrogen uptake by dinoflagellates. J Phycol 20(3): 394-401

Parsons TR, Maita Y, Lalli CM (1984) A manual of chemical and biological methods of seawater analysis. Pergamon Press, Oxford, p 9-14

Prakash A (1967) Growth and toxicity of a marine dinoflagellate, Gonyaulax tamarensis. J Fish Res Bd Can 24(7): $1589-1606$

Rasmussen J, Richardson K (1989) Response of Gonyaulax tamarensis to the presence of a pycnocline in an artificial water column. J Plankton Res 11(4):747-762

Rensel J (1993) Factors controlling paralytic shellfish poisoning (PSP) in Puget Sound, Washington. J Shellfish Res $12(2): 371-376$

Ryther JH, Dunstan WM (1971) Nitrogen, phosphorus, and eutrophication in the coastal marine environment. Science 171:1008-1013

Sakshaug E, Jensen A (1971) Gonyaulax tamarensis and paralytic mussel toxicity in Trondheimsfjorden, 1963-1969. K Nor Vidensk Selsk Skr 15:1-15

Santos BA, Carreto JI (1992) Migraciones verticales de Alexandrium excavatum (Braarud) Balech et Tangen en columnas experimentales. Bolm Inst Oceanogr $S$ Paulo $40(1 / 2): 15-25$

Scarratt MG (1994) Influence of light regimen on the growth and toxicity of Alexandrium tamarense. PhD thesis, Dalhousie University, Halifax

Seliger HH, Tyler MA, McKinley KR (1979) Phytoplankton distributions and red tides resulting from frontal circulation patterns. In: Taylor DL, Seliger HH (eds) Toxic dinoflagellate blooms. Elsevier, New York, p 239-248

Sokal RR, Rohlf FJ (1981) Biometry, 2nd edn. WH Freeman \& Co, San Francisco, p 427-428

Strickland JDH, Parsons TR (1972) A practical handbook of seawater analysis, 2nd edn. Bull Fish Res Bd Can 167:1-310

Vincent WF (1980) Mechanisms of rapid photosynthetic adaptations in natural phytoplankton communities. II. Changes in photochemical capacity as measured by DCMUinduced chlorophyll fluorescence. J Phycol 16:568-577

Watanabe M, Kohata K, Kimura I (1991) Diel vertical migration and nocturnal uptake of nutrients by Chatonella antiqua under stable stratification. Limnol Oceanogr 36(3): $593-602$

White AW (1978) Salinity effects on growth and toxin content of Gonyaulax excavata, a marine dinoflagellate causing paralytic shellfısh poisoning. J Phycol 14:475-479

White AW, Nassif J, Shumway SE, Whittaker DK (1992) Recent occurrence of paralytic shellfish toxins in offshore shellfish in the north-eastern United States. J Shellfish Res $11(1): 209$

Manuscript first reccived: November P, 1996

Revised version accepted: January 28, 1997 